\title{
Gene expression of transporters and phase I/II metabolic enzymes in murine small intestine during fasting Heleen $M$ van den Bosch ${ }^{1,2}$, Meike Bünger ${ }^{1,2}$, Philip J de Groot ${ }^{1,2}$, Jolanda van der Meijde1, Guido JEJ Hooiveld ${ }^{1,2}$ and Michael Müller*1,2
}

\author{
Address: ${ }^{1}$ Nutrition, Metabolism and Genomics group, Division of Human Nutrition, Wageningen, University, Bomenweg 2, 6703 HD \\ Wageningen, The Netherlands and 2Nutrigenomics Consortium, TI Food and Nutrition, Wageningen, The Netherlands \\ Email: Heleen M van den Bosch - heleen.vandenbosch@wur.nl; Meike Bünger - meike.bunger@wur.nl; Philip J de \\ Groot - philip.degroot@wur.nl; Jolanda van der Meijde - jolanda@magicshow.es; Guido JEJ Hooiveld - guido.hooiveld@wur.nl; \\ Michael Müller* - Michael.Muller@wur.nl \\ * Corresponding author
}

Published: 7 August 2007

BMC Genomics 2007, 8:267 doi:10.1/86/|47|-2164-8-267
Received: 5 February 2007

Accepted: 7 August 2007

This article is available from: http://www.biomedcentral.com/I47I-2/64/8/267

(c) 2007 van den Bosch et al; licensee BioMed Central Ltd.

This is an Open Access article distributed under the terms of the Creative Commons Attribution License (http://creativecommons.org/licenses/by/2.0), which permits unrestricted use, distribution, and reproduction in any medium, provided the original work is properly cited.

\begin{abstract}
Background: Fasting has dramatic effects on small intestinal transport function. However, little is known on expression of intestinal transport and phase $\mathrm{I} / \mathrm{Il}$ metabolism genes during fasting and the role the fatty acid-activated transcription factor PPAR $\alpha$ may play herein. We therefore investigated the effects of fasting on expression of these genes using Affymetrix GeneChip MOE430A arrays and quantitative RT-PCR.
\end{abstract}

Results: After 24 hours of fasting, expression levels of 33 of the 253 analyzed transporter and phase I/II metabolism genes were changed. Upregulated genes were involved in transport of energyyielding molecules in processes such as glycogenolysis $(G 6 \mathrm{pt} I)$ and mitochondrial and peroxisomal oxidation of fatty acids (Cact, Mrs3/4, Fatp2, Cyp4al0, Cyp4b/). Other induced genes were responsible for the inactivation of the neurotransmitter serotonin (Sert, SultldI, Dtd, Papst2), formation of eicosanoids (Cyp2j6, Cyp4al0, Cyp4bI), or for secretion of cholesterol (Abcal and Abcg8). Cyp3alI, typically known because of its drug metabolizing capacity, was also increased. Fasting had no pronounced effect on expression of phase II metabolic enzymes, except for glutathione $S$-transferases which were down-regulated. Time course studies revealed that some genes were acutely regulated, whereas expression of other genes was only affected after prolonged fasting. Finally, we identified 8 genes that were PPAR $\alpha$-dependently upregulated upon fasting.

Conclusion: We have characterized the response to fasting on expression of transporters and phase I/II metabolic enzymes in murine small intestine. Differentially expressed genes are involved in a variety of processes, which functionally can be summarized as a) increased oxidation of fat and xenobiotics, b) increased cholesterol secretion, c) increased susceptibility to electrophilic stressors, and d) reduced intestinal motility. This knowledge increases our understanding of gut physiology, and may be of relevance for e.g. pre-surgery regimen of patients. 


\section{Background}

Fasting, the act of willingly abstaining from food, is a frequently occurring natural status in humans. Fasting is a popular strategy to manage overweight or obesity, it is a traditional habit in certain religions or societies, and it is an accepted pre-surgical procedure. During fasting wholebody fuel utilization gradually shifts from carbohydrates and fat in the fed state to proteins and fat after a day of fasting [1]. The nuclear receptor peroxisome proliferatoractivated receptor alpha (PPAR $\alpha$ ) plays an important role in the control of the hepatic metabolic response [2]. During fasting, free fatty acid levels in plasma are elevated and can activate PPAR $\alpha$, which regulates a large array of hepatic genes including those involved in fatty acid catabolism.

The small intestine is the primary organ for digestion and selective absorption of nutrients and other food constituents. Absorption of these molecules across the intestinal epithelium occurs mainly by multiple transmembrane transporters [3-6] that principally belong to two superfamilies, namely the solute carrier (SLC) and the ATP Binding Cassette $(\mathrm{ABC})$ superfamily of transporters $[5,7]$. SLC transporters located at the apical membrane of the enterocyte are responsible for the selective uptake of macronutrients, such as di- and tripeptides, hexoses and fatty acids [8]. In contrast, $\mathrm{ABC}$ transporters are efflux transporters responsible for the active removal of substances, including nutrients such as cholesterol, limiting their intracellular concentrations. Besides their presence in plasma membranes, SLC and ABC transporters are also located in intracellular organelles, such as mitochondria or peroxisomes, in which they are responsible for uptake or secretion of metabolites.

In addition, it has become clear that the intestinal epithelium is an important metabolic site, to a great extend responsible for the first-pass metabolism of nutrients and xenobiotics $[9,10]$. Numerous metabolic reactions occur in enterocytes, including those typically referred to as phase I and phase II metabolism. Phase I metabolism commonly refers to oxidative, peroxidative, and reductive metabolism of endogenous compounds and drugs, mediated by cytochrome P450 isoenzymes (CypP450s) [11]. Phase II metabolism often succeed phase I metabolism and is mediated by several enzymatic systems. In general, phase II metabolism yields conjugated metabolites, increasing the water solubility of lipophilic compounds. The most important phase II enzymes are sulfotransferases (Sults) [12,13], UDP-glucuronosyltransferases (Ugts) [14], glutathione S-transferases (Gsts) $[15,16], \mathrm{N}$ acetyltransferases (Nats) [17], and epoxide hydrolases (Ephs) [18]. Several ABC transporters can secrete metabolites resulting from phase I and phase II enzymatic transformations [19].

Previous studies showed that fasting has a dramatic effect on small intestinal transport function [20]. However, little is known on the expression of transport and phase I/II metabolism genes in small intestine during fasting and the role of PPAR $\alpha$ therein. We therefore set out to investigate the effects of fasting on expression of these genes using microarrays and quantitative RT-PCR (qRT-PCR). We conclude that the absorptive as well as the detoxification capacity of the small intestine is altered during fasting, and that PPAR $\alpha$ mediates a part of the adaptive response to fasting.

\section{Results \\ Effect of 24 hours of fasting on expression of transporter and phase IIII metabolism genes}

The Affymetrix GeneChip Mouse Genome 430A array comprises 22,690 probesets, representing 12,453 unique genes. Annotation information from Affymetrix was queried to compile a list of transporter and phase I/II metabolism genes present on the array (for details, see Methods). This list consisted of 665 probesets, encoding for 436 unique genes, and was used in the remainder of our analyses (Table 1). Under basal, chow-fed conditions, our filtering protocol identified 5,993 significantly expressed genes in the small intestine (i.e. having an absolute expression signal >20), of which 253 were transporters and phase I/II metabolism genes. After 24 hours of fasting, 713 genes, including 33 transporter and phase I/II metabolism genes, were differentially expressed (fold change $>1.3$, p-value $<0.01$ ), corresponding to $13 \%$ of the expressed transporter and phase I/II metabolism genes. For selected genes additional qRT-PCR analyses were performed, which confirmed the array results (Table 2).

Table I: Numbers of expressed and regulated genes in small intestine analyzed on Affymetrix GeneChip MOE430A arrays.

\begin{tabular}{lcc}
\hline & All genes & Transporters + phase I/II metabolism genes \\
\hline Number of probe sets on MOE430A array & 22690 & 665 \\
Number of unique genes on MOE430A array & 12453 & 436 \\
Expressed genes on MOE430A array & 5993 & 253 \\
Regulated after 24 hours of fasting & 713 & 33 \\
Regulated genes, as \% of expressed genes & 11.8 & 13.0 \\
\hline
\end{tabular}

Analysis of all genes on the MOE430A array compared with transporters and phase I/II metabolism genes. 
Table 2: Confirmation of microarray results.

\begin{tabular}{|c|c|c|c|c|c|c|}
\hline Gene symbol & $\begin{array}{l}\text { Affy probe } \\
\text { set ID }\end{array}$ & $\begin{array}{l}\text { FC } \\
\text { microarray }\end{array}$ & $\begin{array}{l}\text { P-value } \\
\text { microarray }\end{array}$ & FC qRT-PCR & $\begin{array}{l}\text { P-value } \\
\text { qRT-PCR }\end{array}$ & Gene name \\
\hline Cyp4al0 & |424853_s_at & 3.6 & 0.0019 & $2.5 \pm 0.34$ & 0.0172 & cytochrome P450, family 4 , subfamily a, polypeptide 10 \\
\hline Сур2j6 & 1417952_at & 2.3 & 0.0000 & $1.7 \pm 0.32$ & 0.0435 & cytochrome P450, family 2, subfamily j, polypeptide 6 \\
\hline Abcal & |42|840_at & 2.3 & 0.0005 & $2.4 \pm 0.26$ & 0.0330 & ATP-binding cassette, sub-family $A(A B C I)$, member I \\
\hline G6ptI (Slc37a4) & |4|7042_at & 2.3 & 0.0010 & $1.9 \pm 0.20$ & 0.0086 & $\begin{array}{l}\text { solute carrier family } 37 \text { (glycerol-6-phosphate } \\
\text { transporter), member } 4\end{array}$ \\
\hline Znt2 (Slc30a2) & I427339_at & 1.9 & 0.0002 & $1.6 \pm 0.24$ & 0.0383 & solute carrier family 30 (zinc transporter), member 2 \\
\hline Abcg8 & |420656_at & 1.8 & 0.0003 & $1.7 \pm 0.29$ & 0.0492 & ATP-binding cassette, sub-family G (WHITE), member 8 \\
\hline Sult IdI & 1418138_at & I.7 & 0.0017 & $1.8 \pm 0.33$ & 0.0310 & sulfotransferase family ID, member I \\
\hline Fatp2 (SIc27a2) & 1416316_at & 1.6 & 0.0003 & $2.0 \pm 0.24$ & 0.0283 & solute carrier family 27 (fatty acid transporter), member 2 \\
\hline Nadcl (Slcl3a2) & |4|8857_at & 1.6 & 0.0011 & $1.6 \pm 0.13$ & 0.0247 & $\begin{array}{l}\text { solute carrier family } 13 \text { (sodium-dependent dicarboxylate } \\
\text { transporter), member } 2\end{array}$ \\
\hline Slc25a36 & 1419656_at & 1.5 & 0.0007 & $2.0 \pm 0.19$ & 0.0114 & solute carrier family 25, member 36 \\
\hline Chst4 & |453393_a_at & 1.4 & 0.0008 & $1.6 \pm 0.13$ & 0.0142 & carbohydrate (chondroitin 6/keratan) sulfotransferase 4 \\
\hline Dtd (Slc26a2) & |42||45_at & 1.4 & 0.0028 & $1.5 \pm 0.06$ & 0.0017 & solute carrier family 26 (sulfate transporter), member 2 \\
\hline Mrs3/4 (Slc25a28) & |424776_a_at & 1.4 & 0.0018 & $1.5 \pm 0.08$ & 0.0141 & solute carrier family 25, member 28 \\
\hline Mgst I & 1415897_a_at & 1.3 & 0.0014 & $2.0 \pm 0.21$ & 0.0078 & microsomal glutathione S-transferase I \\
\hline Сурза丿I & 1416809_at & 1.3 & 0.0057 & $1.9 \pm 0.22$ & 0.0149 & cytochrome P450, family 3 , subfamily a, polypeptide II \\
\hline Mct4 (Slcl 6a3) & |449005_at & -1.6 & 0.0058 & $-1.6 \pm 0.00$ & 0.0329 & $\begin{array}{l}\text { solute carrier family } 16 \text { (monocarboxylic acid } \\
\text { transporters), member } 3\end{array}$ \\
\hline Zip4 (Slc39a4) & |45 | |39_at & -2.4 & 0.0003 & $-2.2 \pm 0.18$ & 0.0472 & solute carrier family 39 (zinc transporter), member 4 \\
\hline Gstm3 & |427473_at & -2.6 & 0.0027 & $-2.2 \pm 0.08$ & 0.0338 & glutathione S-transferase, mu 3 \\
\hline
\end{tabular}

Microarray results were confirmed with qRT-PCR. FC = Fold change, $\mathrm{QRT}$-PCR control samples have been set arbitrarily to I, qRT-PCR data are means \pm standard error $(n=3)$.

\section{Solute carrier transporters}

We studied 243 SLC transporters, which amounts to $68 \%$ of the total number transporters of this superfamily currently known (see additional file 1 ). After 24 hours of fasting, 16 SLC transporters were differentially expressed (Table 3), which corresponded to $15 \%$ of the expressed SLC transporter genes in the small intestine. With respect to apical transporters, expression of the short-chain fatty acid transporter Smct1 (Slc5a8) [21], the carboxylate transporter Nadc1 (Slc13a2) [22], the prostaglandin transporter Pgt (Slco2a1) [23], and the sulphate transporter Dtd (Slc26a2) [24] was increased, whereas the expression level of the zinc transporter Zip4 (Slc39a4) [25] was suppressed. The basolaterally located monocarboxylate transporter Mct4 (Slc16a3) [26] and iron transporter Ireg1 (Slc40a1) [27] were downregulated, and the basolateral neurotransmitter serotonin transporter Sert (Slc6a4/5HTT) [28], was upregulated. Seven intracellular SLC transporters were induced (Table 3); Znt2 (Slc30a2), G6pt1 (Slc37a4), Fatp2 (Slc27a2), Papst2 (Slc35b3), Cact (Slc25a20), Mrs3/4 (Slc25a28), and Slc25a36. Znt2 [29] is responsible for storage of zinc in sub-apically-located vesicles. G6pt1 [30] and Fatp2 [31] are localized at the endoplasmic reticulum, transporting glucose- 6 phosphate and fatty acyl-CoA esters, respectively. The sulphate donor 3'phosphoadenosine 5'-phosphosulfate (PAPS) transporter Papst2 [32] is localized in the Golgi. Finally, Cact, Mrs3/4 and Slc25a36 are all three present in mitochondria shuttling metabolites across the inner mitochondrial membrane [33]. Cact and Mrs3/4 transport fatty acyl carnitines for fatty acid oxidation and iron, respectively. The function of Slc25a36 is currently not known. Finally, Fuct1
(Slc35c1) [34] an additional member of the Slc35 family, transporting nucleotide sugars, was downregulated.

\section{Phase I and II metabolic genes}

Next we evaluated the effects of fasting on expression of phase I/II metabolism genes (see additional file 2). Results are presented in Table 4. We studied 61 CypP450s, which corresponds to $66 \%$ of the currently known mouse CypP450s. Five CypP450s were differentially expressed, corresponding to $29 \%$ of the expressed CypP450s in small intestine. Cyp2j6 was upregulated. Members of the Cyp2 family are well known to be responsible for the NADPHdependent oxidation of steroids and fatty acid as well as drugs [11]. In addition, expression of Cyp3a11, typically known because of its drug-metabolizing capacity [11], was increased. Finally, Cyp4a10 and Cyp4b1, involved in peroxisomal oxidation of fatty acids, and Cyp27a1, involved in conversion of cholesterol into 27-hydroxycholesterol, were all induced upon fasting [11,35,36]. With respect to phase II metabolism, expression of in total 89 enzymes was analyzed (see additional file 2). Except for Gsts, fasting had no denoting effect on expression of phase II metabolism genes (Table 4), since only 3 nonGsts were changed. Apart from Gstm1, all changed Gsts were downregulated. The aldo-keto reductase Akr1b7 [37], involved in detoxification of lipid peroxides, and two sulfotransferases, Sult1d1 and Chst4, were increased.

\section{$A B C$ transporters}

Effects of fasting on expression of $\mathrm{ABC}$ transporters are summarized in Table 5 . We analyzed 40 of the 52 murine $\mathrm{ABC}$ transporters (see additional file 3 ). The transporters 
Table 3: Differential expressed SLC transporters in the small intestine after $24 \mathrm{~h}$ fasting.

\begin{tabular}{|c|c|c|c|c|c|c|c|c|}
\hline Gene symbol & $\begin{array}{l}\text { Affy probe } \\
\text { set ID }\end{array}$ & $\begin{array}{c}\text { A } \\
\text { value }\end{array}$ & $\begin{array}{l}\text { SD WT } \\
0 \text { hr }\end{array}$ & $\begin{array}{l}\text { SDWT } \\
24 \mathrm{hr}\end{array}$ & $\begin{array}{l}\text { Fold } \\
\text { change }\end{array}$ & $\begin{array}{c}\text { P- } \\
\text { value }\end{array}$ & Localization & Gene name \\
\hline G6ptI (SIc37a4) & 1417042_at & 7.7 & 0.44 & 0.37 & 2.3 & 0.0010 & Endoplasmatic reticulum & $\begin{array}{l}\text { Solute carrier family } 37 \text { (glycerol-6- } \\
\text { phosphate transporter), member } 4\end{array}$ \\
\hline Znt2 (SIc30a2) & 1427339_at & 5.6 & 0.09 & 0.30 & 1.9 & 0.0002 & Vesicles & $\begin{array}{l}\text { Solute carrier family } 30 \text { (zinc transporter), } \\
\text { member } 2\end{array}$ \\
\hline Slc25a36 & 1419656_at & 6.7 & 0.09 & 0.22 & 1.7 & 0.0002 & Mitochondria & Solute carrier family 25 , member 36 \\
\hline Fatp2(SIc27a2) & 1416316_at & 10.4 & 0.19 & 0.11 & 1.6 & 0.0003 & Peroxisomes and ER & $\begin{array}{l}\text { Solute carrier family } 27 \text { (fatty acid } \\
\text { transporter), member } 2\end{array}$ \\
\hline Nadcl (Slcl3a2) & 1418857_at & 10.2 & 0.23 & 0.15 & 1.6 & 0.0011 & Apical & $\begin{array}{l}\text { Solute carrier family } 13 \text { (sodium- } \\
\text { dependent dicarboxylate transporter), } \\
\text { member } 2\end{array}$ \\
\hline Slc25a36 & 1419657_a_at & 9.4 & 0.16 & 0.14 & 1.5 & 0.0007 & Mitochondria & Solute carrier family 25 , member 36 \\
\hline Papst2 (Slc35b3) & 1448937_at & 7.6 & 0.04 & 0.18 & 1.5 & 0.0005 & Golgi & Solute carrier family 35 , member B3 \\
\hline Smct I (SIc5a8) & 1425606_at & 6.5 & 0.14 & 0.12 & 1.5 & 0.0009 & Apical & $\begin{array}{l}\text { Solute carrier family } 5 \text { (iodide } \\
\text { transporter), member } 8\end{array}$ \\
\hline Cact (SIc25a20) & |423 108_at & 9.2 & 0.04 & 0.07 & 1.4 & 0.0002 & Mitochondria & $\begin{array}{l}\text { Solute carrier family } 25 \text { (mitochondrial } \\
\text { carnitine/acylcarnitine translocase), } \\
\text { member } 20\end{array}$ \\
\hline Cact (Slc25a20) & 1423109_s_at & 7.9 & 0.10 & 0.19 & 1.4 & 0.0019 & Mitochondria & $\begin{array}{l}\text { Solute carrier family } 25 \text { (mitochondrial } \\
\text { carnitine/acylcarnitine translocase), } \\
\text { member } 20\end{array}$ \\
\hline Sert (Slc6a4) & 1417|50_at & 8.5 & 0.18 & 0.07 & 1.4 & 0.0014 & Basolateral & $\begin{array}{l}\text { Solute carrier family } 6 \text { (neurotransmitter } \\
\text { transporter, serotonin), member } 4\end{array}$ \\
\hline Mrs3/4 (Slc25a28) & 1424776_a_at & 7.0 & 0.12 & 0.17 & 1.4 & 0.0018 & Mitochondria & Solute carrier family 25 , member 28 \\
\hline Dtd (Slc26a2) & |42||45_at & 5.6 & 0.06 & 0.22 & 1.4 & 0.0028 & Apical & $\begin{array}{l}\text { Solute carrier family } 26 \text { (sulfate } \\
\text { transporter), member } 2\end{array}$ \\
\hline Oatp2al (Slco2al) & |4209|3_at & 8.3 & 0.06 & 0.17 & 1.4 & 0.0023 & Apical & $\begin{array}{l}\text { Solute carrier organic anion transporter } \\
\text { family, member } 2 \mathrm{al}\end{array}$ \\
\hline Fuct I (Slc35cl) & 1452139_at & 7.3 & 0.16 & 0.36 & -1.4 & 0.0052 & Golgi & Solute carrier family 35 , member $\mathrm{Cl}$ \\
\hline IregI (Slc40al) & |41706|_at & 8.1 & 0.38 & 0.35 & -1.6 & 0.0099 & Basolateral & $\begin{array}{l}\text { Solute carrier family } 40 \text { (iron-regulated } \\
\text { transporter), member I }\end{array}$ \\
\hline Mct4 (SIcl6a3) & |449005_at & 4.2 & 0.44 & 0.21 & -1.6 & 0.0058 & Basolateral & $\begin{array}{l}\text { Solute carrier family } 16 \text { (monocarboxylic } \\
\text { acid transporters), member } 3\end{array}$ \\
\hline IregI (Slc40aI) & |448566_at & 7.8 & 0.48 & 0.50 & -1.7 & 0.0084 & Basolateral & $\begin{array}{l}\text { Solute carrier family } 40 \text { (iron-regulated } \\
\text { transporter), member I }\end{array}$ \\
\hline Zip4 (Slc39a4) & |45 | |39_at & 9.0 & 0.04 & 0.48 & -2.0 & 0.0003 & Apical & $\begin{array}{l}\text { Solute carrier family } 39 \text { (zinc transporter), } \\
\text { member } 4\end{array}$ \\
\hline
\end{tabular}

$A=$ the average log2 transformed expression value of normal fed and 24 hours fasted mice $(n=3)$, SD = standard deviation, WT = wild-type mice. In addition to the fold change, the intracellular localization of the corresponding protein is given.

Abca1 [38], involved in basolateral efflux of cholesterol, and Abcg8 [39], involved in transport of sterols and stanols across the apical membrane, were upregulated.

Time dependent changes of gene expression during fasting To get insight into the time-dependent effects of fasting, we performed an additional experiment in which mice were deprived of food for various time points up to 24 hours. Intestinal weight, blood glucose and plasma free fatty acid levels were measured (Figure 1). As expected, blood glucose levels decreased until 12 hours of fasting, after which it stabilized [2]. Free fatty acid levels rapidly increased at the onset of fasting, and remained constant after 18 hours. Intestinal weight decreased already after 3 hours of fasting, significant changes were found as from 12 hours of fasting. For selected transporters and phase I/ II metabolism enzymes gene expression was measured using qRT-PCR (Figure 2). Genes were selected based on function and array data. Several genes were regulated gradually in time and seemed to follow the same pattern as the free fatty acid concentration (Fatp2, Znt2, G6pt1,
Zip4, Cyp27a1, Cyp2j6, and Sult1d1). Other genes were acutely regulated (Nadc1, Znt2, Zip4, Cyp27a1, Sult1d1, Gstm3, and Abca1.) In this group Nadc1 and Gstm3 were most drastic regulated after 3 hours fasting. Finally, a group of genes responded only after prolonged fasting (G6pt1, Fatp2, Mct4, Cyp4a10, Cyp3a11, Cyp2j6, and Abcg8). These data indicate that different mechanisms underlay the response to fasting.

\section{Role of PPAR $\alpha$ during fasting}

It has been shown that PPAR $\alpha$ is an important mediator of the hepatic adaptive response to fasting [2]. Therefore we evaluated the role of this transcription factor in regulating transporter and phase I/II metabolism genes in small intestine during fasting. To this end, the effect of 24 hours fasting was compared in wild-type and PPAR $\alpha$ knockout mice (Table 6). Eight of the genes identified in wild-type mice were PPAR $\alpha$-dependently regulated, which corresponded to $24 \%$ of all genes regulated. No genes were found to be suppressed in a PPAR $\alpha$ dependent 
Table 4: Differential expressed detoxification genes in the small intestine after $24 \mathrm{~h}$ fasting.

\begin{tabular}{|c|c|c|c|c|c|c|c|}
\hline Gene symbol & Affy probe set ID & A value & SD WT 0 hr & SD WT 24 hr & Fold change & P-value & Gene name \\
\hline \multicolumn{8}{|l|}{ CYPP450s } \\
\hline Cyp4aI0 & |424853_s_at & 7.4 & 0.96 & 0.37 & 3.6 & 0.0019 & $\begin{array}{l}\text { Cytochrome P450, family } 4 \text {, subfamily a, } \\
\text { polypeptide } 10\end{array}$ \\
\hline Сур27al & |417590_at & 8.4 & 0.12 & 0.50 & 3.1 & 0.0001 & $\begin{array}{l}\text { Cytochrome P450, family } 27 \text {, subfamily a, } \\
\text { polypeptide I }\end{array}$ \\
\hline Сур2j6 & |4|7952_at & 8.3 & 0.22 & 0.11 & 2.3 & 0.0000 & $\begin{array}{l}\text { Cytochrome P450, family } 2 \text {, subfamily j, } \\
\text { polypeptide } 6\end{array}$ \\
\hline Cyp4bl & 1416194_at & 9.7 & 0.20 & 0.22 & 2.2 & 0.0000 & $\begin{array}{l}\text { Cytochrome P450, family } 2 \text {, subfamily c, } \\
\text { polypeptide } 29\end{array}$ \\
\hline СурзаІІ & 1416809_at & 11.0 & 0.07 & 0.10 & 1.3 & 0.0057 & $\begin{array}{l}\text { Cytochrome P450, family } 3 \text {, subfamily a, } \\
\text { polypeptide II }\end{array}$ \\
\hline \multicolumn{8}{|l|}{ GSTs } \\
\hline Mgst l & 1415897_a_at & 11.1 & 0.05 & 0.08 & 1.3 & 0.0014 & Microsomal glutathione S-transferase I \\
\hline Gstp I & |449575_a_at & 11.9 & 0.14 & 0.13 & -1.4 & 0.0027 & Glutathione S-transferase, pi I \\
\hline Gstm5 & 1416842_at & 7.1 & 0.12 & 0.05 & -1.5 & 0.0002 & Glutathione S-transferase, mu 5 \\
\hline Gstt I & 1418186_at & 7.1 & 0.21 & 0.06 & -1.7 & 0.0001 & Glutathione S-transferase, theta I \\
\hline Gstm3 & |427473_at & 5.4 & 0.44 & 0.45 & -2.6 & 0.0006 & Glutathione S-transferase, mu 3 \\
\hline Gstm4 & 1424835_at & 4.5 & 0.60 & 0.38 & -2.7 & 0.0009 & Glutathione S-transferase, mu 4 \\
\hline Gstm3 & |427474_s_at & 9.2 & 0.36 & 0.79 & -2.8 & 0.0027 & Glutathione S-transferase, mu 3 \\
\hline \multicolumn{8}{|l|}{ SULTs } \\
\hline Sult IdI & 1418138_at & 9.9 & 0.15 & 0.33 & 1.7 & 0.0017 & Sulfotransferase family ID, member I \\
\hline Chst4 & |453393_a_at & 4.7 & 0.04 & 0.08 & 1.4 & 0.0008 & $\begin{array}{l}\text { Carbohydrate (chondroitin 6/keratan) } \\
\text { sulfotransferase } 4\end{array}$ \\
\hline \multicolumn{8}{|l|}{ AKRs } \\
\hline Akrlb7 & |423556_at & 10.3 & 0.04 & 0.63 & 2.5 & 0.0008 & Aldo-keto reductase family I, member B7 \\
\hline
\end{tabular}

$A=$ the average log2 transformed expression value of normal fed and 24 hours fasted mice $(n=3)$, SD $=$ standard deviation $(n=3)$, WT $=$ wild-type mice.

manner. qRT-PCR was used to confirm the differential expression of Cyp4a10, Abca1, and Slc25a36 (Figure 3).

\section{Discussion}

In this study we set out to determine the effect of fasting on several aspects directly related to the primary function of the small intestine; the selective absorption and metabolism of food components. We find that of all genes encoding transport proteins and phase I/II metabolic enzymes, approximately 13\% were changed due to 24 hours of fasting. Effects on gene expression are dependent on the length of food deprivation, and PPAR $\alpha$ is required for the adaptive response of a subset of genes. A summary of hypothetical functional outcomes of fasting in the murine small intestine is presented in Figure 4, and detailed below. Although in this study we only determined mRNA levels, it has been reported that for the majority of genes the mRNA levels reflect protein abun- dance very well $[40,41]$. We therefore allow ourselves to speculate about the functional consequences of fasting. Nevertheless, these implications should ultimately be evaluated in follow-up studies.

Changes in intestinal structure upon fasting differ between species [20]. Although we did not investigate this in the current study, both Lenaerts et al. [42] and Chappell et al. [43] observed only minor changes on murine mucosal structure upon fasting. In addition, if occurring, we believe that changes on tissue base do not affect our gene expression data, because otherwise we should have seen more pronounced differences on gene expression level.

An array of intestinal transporters and phase I and II metabolic enzymes are required to handle adequately various endogenous molecules, food components including

Table 5: Differential expressed ABC transporters in the small intestine after $24 \mathrm{~h}$ fasting.

\begin{tabular}{|c|c|c|c|c|c|c|c|c|}
\hline $\begin{array}{l}\text { Gene } \\
\text { symbol }\end{array}$ & $\begin{array}{l}\text { Affy probe } \\
\text { set ID }\end{array}$ & $\begin{array}{c}A \\
\text { value }\end{array}$ & $\begin{array}{c}\text { SD WT } 0 \\
\mathrm{hr}\end{array}$ & $\begin{array}{l}\text { SD WT } \\
24 \mathrm{hr}\end{array}$ & $\begin{array}{c}\text { Fold } \\
\text { change }\end{array}$ & P-value & Localization & Gene name \\
\hline Abcal & 1421840_at & 6.266 & 0.28 & 0.44 & 2.3 & 0.0005 & Basolateral (secretion) & ATP-binding cassette, sub-family $A(A B C I)$, member I \\
\hline Abcg8 & |420656_at & 8.037 & 0.18 & 0.25 & 1.8 & 0.0003 & Apical (secretion) & ATP-binding cassette, sub-family G (WHITE), member 8 \\
\hline
\end{tabular}

$A=$ the average $\log 2$ transformed expression value of normal fed and 24 hours fasted mice $(n=3), S D=$ standard deviation, WT $=$ wild-type mice. In addition to the fold change, the intracellular localization of the corresponding protein is given. 

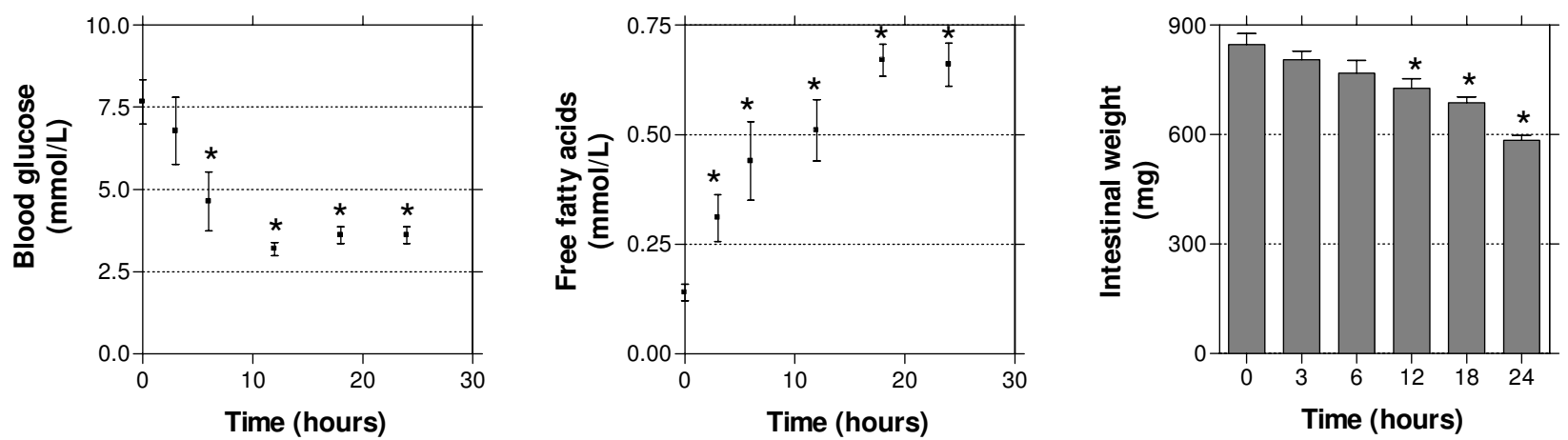

Figure I

Blood glucose levels, free fatty acid levels, and small intestinal weight during fasting. Significance was determined using an unpaired student's $t$-test. * P-value $<0.05$. Bars represent standard error.

nutrients and xenobiotics. Our finding that 24 hours of fasting results in the differential expression of $13 \%$ of the transporter and phase I/II metabolism genes has implications for metabolism of the different types of substrates.

\section{Regulation of genes involved in intestinal motility}

Expression of the serotonin transporter Sert was increased after 24 hours of fasting. Serotonin, a neurotransmitter secreted by enterochromaffin cells, is considered to play a key role in normal functioning of the gut, initiating peristaltic reflex pathways and facilitating propulsive activity. Sert-mediated uptake of serotonin in enterocytes is responsible for the termination of the action of serotonin in the intestine [28]. After a meal, the small intestine exhibits a pattern of phasic contractions of various amplitudes [44]. During fasting, these phasic contractions are replaced by a cyclic pattern with less frequent contractions, enough to propel undigested food residues and sloughed enterocytes. As it is known that serotonin increases the frequency of intestinal contractions [45], removal of serotonin by Sert preserves these lower motility reflexes during fasting. Sult $1 d 1$ is involved in the sulfation of serotonin for the serotonin removal in enterocytes [46]. For this conjugation the activated form of sulphate, PAPS, is needed. Sult1d1, the apical sulphate transporter $D t d$, and the PAPS transporter Papst2 were all upregulated during fasting. We believe that the coordinated induction of these enzymes is required to maintain the lower peristaltic reflexes during fasting (Figure 4B).

\section{Regulation of genes involved in metabolism of energy- yielding substrates}

Fasting increased the expression of Cact and Fatp2, and G6pt1, three intracellular SLC transporters involved in transport of substrates of mitochondrial $\beta$-oxidation and glycogenolysis, respectively $[30,31,33,47]$. Changes in gene expression of these transporters coincided with differential gene expression of enzymes involved in both processes (data not shown). In addition, the increased expression of Cyp4a10 and Cyp4b1 points to enhanced peroxisomal oxidation of fatty acids [11], and an elevated level of Nadc1 implies increased uptake from luminal dicarboxylates (Krebs cycle intermediates) as well as citrate secreted by pancreatic and gastric juice [48]. Thus, these changes reflect the molecular events caused by the switch of fuel utilization from carbohydrates to fatty acid oxidation (Figure 4A).

\section{Regulation of genes involved in cholesterol efflux}

Cholesterol can be secreted from enterocytes by chylomicrons and by the efflux transporters Abca1 and Abcg5/g8. Expression of the cholesterol efflux transporters $A b c a 1$ and $A b c g 8$ was increased upon fasting. Since both carriers are LXR target genes $[49,50]$ we believe this is due to the profoundly increased expression levels of Cyp27a1, which results in enhanced levels of the potent LXR agonist 27hydroxycholesterol [51]. Since during fasting no cholesterol is required for chylomicron formation, we speculate this may be a compensatory mechanism for the enterocyte to balance its intracellular cholesterol concentrations (Figure 4C).

Regulation of genes involved in metabolism of xenobiotics Various CypP450s with well-known drug-metabolizing capacity were differentially expressed after fasting (Cyp2j6, Cyp3a11, and Cyp4b1). Increased expression of Cyp3a11 after fasting has also been observed in rat liver [52]. Although Cyp3a11 does not have a direct human ortholog, it has similar substrate specificity as human CYP3A4. CYP3A4 is considered to be the major metabolizing enzyme of approximately half of the drugs in use 
A SLC transporters
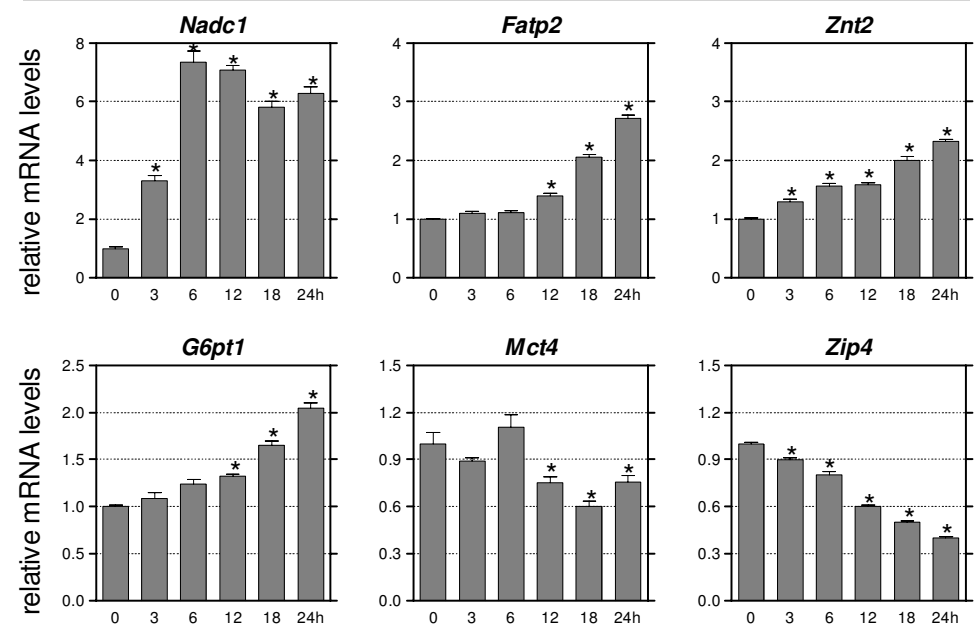

$\mathrm{B}$

Phase $1 / /$ metabolism genes
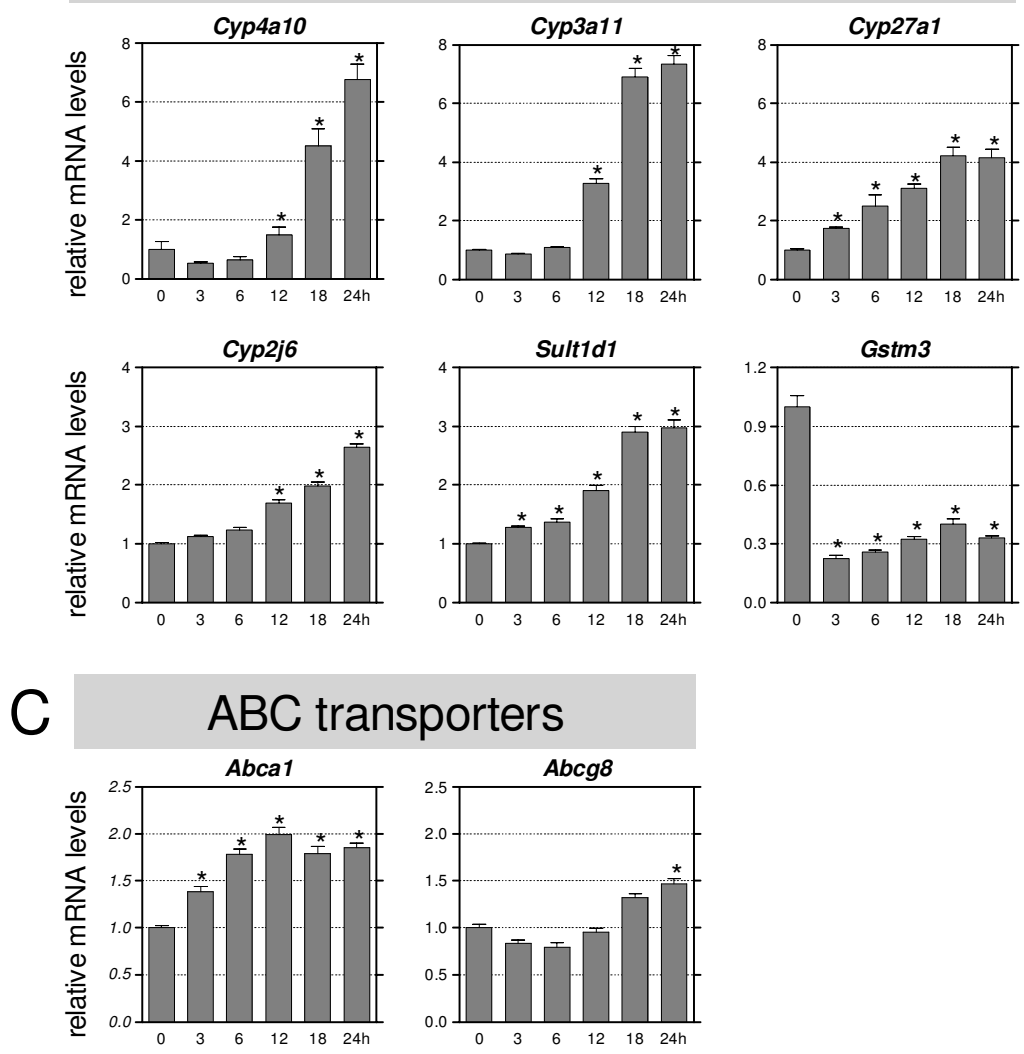

\section{Figure 2}

Time dependent changes in gene expression during fasting. The horizontal axis indicates the hours of fasting. Significance was determined using an unpaired student's $t$-test. * P-value $<0.05$. Data are presented as mean \pm standard error, $\mathrm{n}=6-$ 10. qRT-PCR results of SLC transporters. (B) qRT-PCR results of detoxification genes. (C) qRT-PCR results of ABC transporters. 
Table 6: PPAR $\alpha$ regulated genes during fasting.

\begin{tabular}{|c|c|c|c|c|c|}
\hline Gene Symbol & Probe Set ID & FC WTc vs WT 24 hr & P-value WT & FC KOc vs KO 24 hr & A value $\mathbf{W T}$ \\
\hline Cyp4al0 & |424853_s_at & 3.6 & 0.0019 & $\mathrm{NC}$ & 7.4 \\
\hline Abcal & |421840_at & 2.3 & 0.0005 & $\mathrm{NC}$ & 6.3 \\
\hline Slc25a36 & 1419656_at & 1.7 & 0.0002 & $\mathrm{NC}$ & 6.7 \\
\hline Slc25a36 & |419657_a_at & 1.5 & 0.0007 & $\mathrm{NC}$ & 9.4 \\
\hline Smctl, Slc5a8 & |425606_at & 1.5 & 0.0009 & $\mathrm{NC}$ & 6.5 \\
\hline Sert, Slc6a4 & |417|50_at & 1.4 & 0.0014 & $\mathrm{NC}$ & 8.5 \\
\hline Dtd, Slc26a2 & |42||45_at & I.4 & 0.0028 & $\mathrm{NC}$ & 5.6 \\
\hline Chst4 & |453393_a_at & $\mathrm{I} .4$ & 0.0008 & $\mathrm{NC}$ & 4.7 \\
\hline Mgst I & |4|5897_a_at & 1.3 & 0.0014 & $\mathrm{NC}$ & II.I \\
\hline
\end{tabular}

FC $=$ Fold change, $\mathrm{WT}=$ wild-type mice. $\mathrm{KO}=\mathrm{PPAR} \alpha$-null mice, $\mathrm{A}=$ the average log 2 transformed expression value of normal fed $(\mathrm{c})$ and 24 hours $(24$ hr) fasted mice $(n=3)$.

today [53]. Our results indicate that upon a fasting period drugs may be more efficiently detoxified (Figure 4D), which is of relevance e.g. during surgical interventions in patients.

Except for Gsts, which were expressed at reduced levels, fasting had no denoting effect on expression of phase II metabolism genes. GSH plays an important role in the defense against oxidative stress [54], and is required as cofactor for glutathione peroxidase (GPx) and glutathione S-transferase (Gst) activity. GPx detoxifies peroxides using GSH as an electron donor, producing GSSG as end product which in turn is converted back into GSH by glutathione reductase (Gsr). Gsts catalyze the conjugation of GSH to a wide variety of endogenous and exogenous electrophilic compounds. It is known that upon fasting levels of GSH are reduced in small intestine and liver [55-57], likely as a result of increased oxidation and decreased presence of its dietary precursory amino acids [58]. We believe these reduced GSH levels may be responsible for the observed reduced mRNA levels of the glutathione Stransferase (Gsts), since it is known that expression levels of Gsts are directly dependent on the presence of GSH [59]. In addition, it is known that dietary electrophiles are
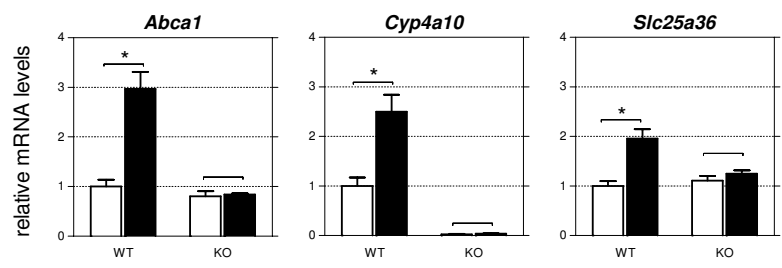

Figure 3

qRT-PCR results of PPAR $\alpha$ dependently regulated genes during fasting. White bars represent the control group, black bars represent the 24 hours fasted group. Significance was determined using an unpaired student's $t$-test. * Pvalue $<0.05$. Data are presented as mean \pm standard error, $n$ $=3$. able to activate the transcription factor Nrf2, which can activate among others Gsts [60]. During fasting these dietary electrophiles are not available, which may be an additional explanation for the reduced expression levels of Gsts. The time dependent fasting experiment showed that the reduction of Gstm3 is a very acute process. Thus, regardless the underlying mechanism, the reduced GSH and Gsts levels will render the fasting gut more sensitive towards electrophilic stressors and other Gst substrates, which may have implications for humans on drug therapy during fasting and the period directly thereafter (Figure $4 \mathrm{E})$.

\section{Role of PPAR $\alpha$ during fasting}

We showed that eight of the transporters and phase I/II metabolism genes were PPAR $\alpha$ dependently regulated during fasting (Figure 4F). Genes that were most prominently regulated by PPAR $\alpha$ were involved in lipid metabolism (Cyp4a10, Abca1, and Smct1). In liver Cyp4a10 and Abca1 are known to be regulated via PPAR $\alpha$ during fasting $[61,62]$. Furthermore, Cyp4a10 is a known PPAR $\alpha$ target gene [63]. It has also been reported that Abca1 is regulated by PPAR $\alpha$ [64], although no PPAR responsive elements have been identified in its promoter region [65]. Sert and Dtd were PPAR $\alpha$ dependently regulated, which indicates that PPAR $\alpha$ may link nutritional status to peristaltic movement. Sert, Dtd, Slc25a36, Smct1, Chst4, and Mgst1 have all not been identified yet as PPAR $\alpha$ target genes. We conclude that PPAR $\alpha$ is required for the adaptive response of a subset of genes.

\section{Conclusion}

In this study we provide an overview of the effects of fasting on expression of transporter and phase I/II metabolism genes in the small intestine. Twenty-four hours of fasting had a high impact on gene expression of murine small intestinal transporter and phase I/II metabolism genes. In addition, we demonstrated that the effects on gene expression are dependent on the length of food deprivation. Affected processes can functionally be summa- 


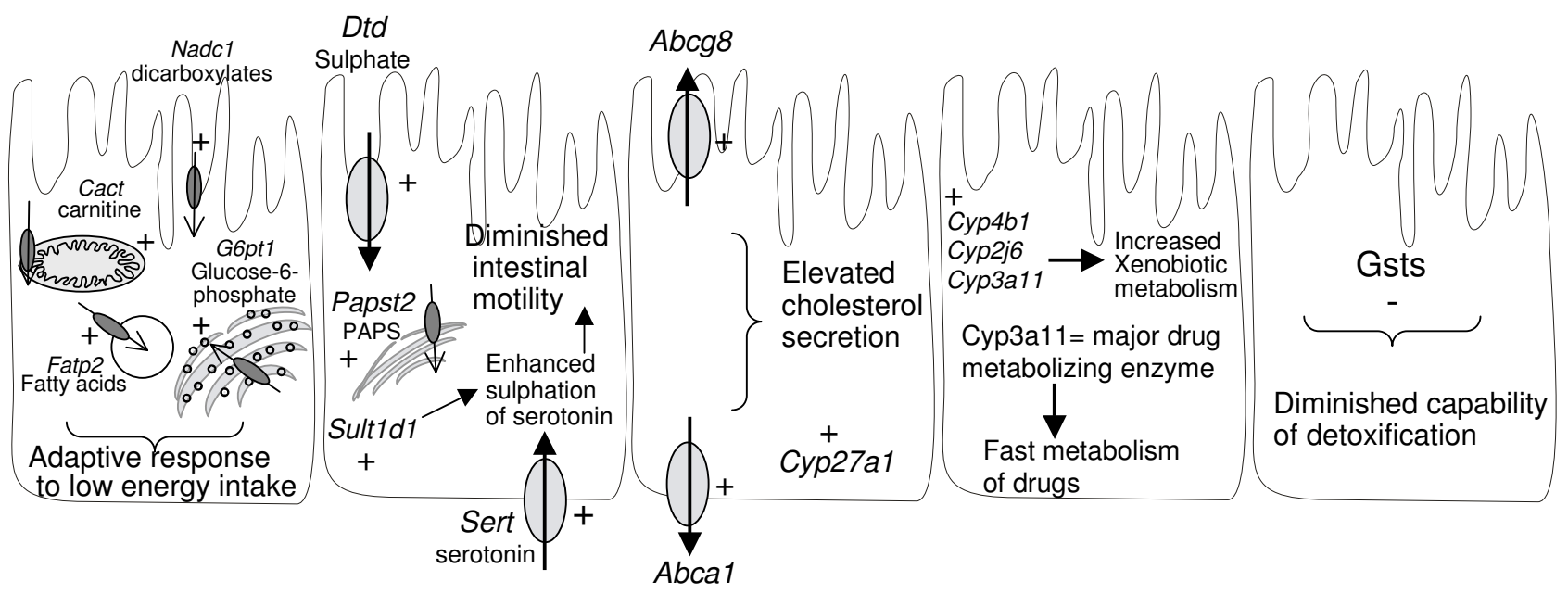

\section{Figure 4}

Hypothetical schematic overview of effects of fasting on small intestinal transporters and phase I/II metabolism genes. Not all results are summarized in this figure. The direction of transport is shown ( $\uparrow)$ in the transporters, + means upregulated and - means downregulated during fasting. (A) Increased energy metabolism. (B) Diminished intestinal motility. (C) Elevated cholesterol secretion. (D) Increased xenobiotic metabolism. (E) Diminished capability of detoxification. (F) PPAR $\alpha$ dependent regulated genes.

rized as a) increased oxidation of fat and xenobiotics, b) increased activation of PPAR $\alpha, c)$ increased cholesterol secretion, d) increased susceptibility to electrophilic stressors, and e) reduced intestinal motility. Finally, we showed that PPAR $\alpha$ mediates a part of the adaptive response to fasting.

\section{Methods}

\section{Animals}

Pure bred wild-type (129S1/SvImJ) and PPAR $\alpha$-null (129S4/SvJae) mice [66] were purchased from Jackson Laboratories (Bar Harbor, ME) and bred at the animal facility of Wageningen University. Mice were housed in a light- and temperature-controlled facility and had free access to water and standard laboratory chow (RMH-B, Hope Farms, Woerden, the Netherlands). All animal studies were approved by the Local Committee for Care and Use of Laboratory Animals.

\section{Experimental design and tissue handling}

Three to four month old male PPAR $\alpha$-null and wild-type mice were fasted for several time points up to 24 hours. Fasting experiments started at the onset of the light cycle. Mice were anaesthetized with a mixture of isofluorane $(1.5 \%)$, nitrous oxide $(70 \%)$ and oxygen $(30 \%)$. Blood was collected via orbital puncture, plasma was obtained by centrifuging at $200 \mathrm{~g}$ for 10 minutes and stored at $80^{\circ} \mathrm{C}$ until use. The small intestines were excised, flushed with ice-cold PBS, and weighted. Remaining fat and pancreatic tissue was carefully removed and the small intes- tine was snap-frozen in liquid nitrogen and stored at $80^{\circ} \mathrm{C}$ until RNA isolation.

\section{RNA isolation and quality control}

Total RNA was isolated from small intestinal samples using TRIzol reagent (Invitrogen, Breda, the Netherlands) according to the manufacturer's instructions. RNA was treated with DNAse and purified using the SV total RNA isolation system (Promega, Leiden, the Netherlands). Concentrations and purity of RNA samples were determined on a NanoDrop ND-1000 spectrophotometer (Isogen, Maarssen, the Netherlands). RNA integrity was checked on an Agilent 2100 bioanalyzer (Agilent Technologies, Amsterdam, the Netherlands) with 6000 Nano Chips according to the manufacturer's instructions. RNA was judged as suitable for array hybridization only if samples exhibited intact bands corresponding to the $18 \mathrm{~S}$ and $28 \mathrm{~S}$ ribosomal RNA subunits, and displayed no chromosomal peaks or RNA degradation products.

\section{Affymetrix GeneChip oligoarray hybridization and scanning}

For microarray analyses, we used RNA isolated from the full-length small intestine. RNA was hybridized on an Affymetrix GeneChip Mouse Genome 430A array. This array detects 22,690 transcripts that represent 12,453 known genes. For each experimental group, three biological replicated were hybridized, thus in total 12 arrays were used. Detailed methods for the labeling and subsequent hybridizations are available on request. Arrays were 
scanned on a GeneChip Scanner 3000 (Affymetrix). Array data have been submitted to the Gene Expression Omnibus, accession number GSE6864.

\section{Analyses of microarray data}

Scans of the Affymetrix arrays were processed using packages from the Bioconductor project [67]. Expression levels of probe sets were estimated using the library GCRMA [68], where after differentially expressed probe sets were identified using linear models [69]. The library LIMMA implements an empirical Bayes method to assign differential gene expression, an approach repeatedly shown to be the most appropriate [70-73]. To compile a list of transporter and phase I/II metabolism genes present on the array, annotation information from Affymetrix (release of July 2006) was queried for SLC transporters, ABC transporters, CypP450s, the phase II metabolism enzymes glutathione S-transferases, sulfotransferases, epoxide hydrolases, aldo-keto reductases, N-acetyltransferases, and glucuronosyl transferases. Also glutathione reductase, glutathione synthetase, and glutathione peroxidases were included in this set. The final set consisted of 665 probesets, encoding for 436 unique genes (Table 1). To study significantly expressed genes, only probesets with an expression value higher than 20 in the WT control group were selected for further analysis. This filtering was done after normalization. Probe sets that satisfied the criterion of $>1.3$ fold change with a p-value $<0.01$ were considered to be significantly regulated. Of these, probe sets that were not changed in fasted PPAR $\alpha$-knockout mice, were designated PPAR $\alpha$ regulated. Interpretations of functional outcomes of fasting focused on groups of genes that are known to be functionally related (i.e. participating in the same pathway or having a similar function). Although at first sight the fold change threshold may seem to be low, we could confirm all changes in gene expression identified on the microarray (Table 2). Moreover, we would like to stress that it is generally accepted that effects of nutritional interventions on gene expression are subtle, in contrast to pharmacological-type of interventions [7476]. A clear example of this is found in Patsouris et al. [10], in which the effect of pharmacological, physiological, and nutritional intervention on expression of the same set of genes were compared.

\section{Quantitative Real-time PCR}

Single-stranded complementary DNA (cDNA) was synthesized from $1 \mu \mathrm{g}$ of total RNA using the Reverse transcription system (Promega, Leiden, The Netherlands) following the supplier's protocol. cDNA was PCR amplified with Platinum Taq DNA polymerase (all reagents were from Invitrogen). Primer sequences used in the PCR reaction were chosen based on the sequences available in GenBank. The sequence of primers used is available in Table 7. PCR was carried out using SYBR green on a MyIQ thermal cycler (Bio-Rad laboratories BV, Veenendaal, The Netherlands) with the following thermal cycling conditions: $8 \mathrm{~min}$ at $94^{\circ} \mathrm{C}$, followed by 45 cycles of $94^{\circ} \mathrm{C}$ for 15 $\mathrm{s}$ and $60^{\circ} \mathrm{C}$ for $1 \mathrm{~min}$. All samples were performed in duplicate and normalized to cyclophilin expression.

\section{Free fatty acids and blood glucose levels}

Free fatty acids were measured with the Free fatty acids half-micro test (Roche Diagnostics, Almere, The Nether-

Table 7: Primer sequences.

\begin{tabular}{cll}
\hline Gene symbol & Forward primer & Reverse primer \\
\hline Abcal & CCCAGAGCAAAAAGCGACTC & \\
Abcg8 & AGTGGTCAGTCCAACACTCTG & CCCAGAGCAAAAAGCGACTC \\
Chst4 & GTCTTTGATGCCTACATGAACCC & GAGACCTCCAGGGTATCTTGAA \\
Cyclophilin & CAGACGCCACTGTCGCTTT & GTGGGCAGGGAAGAAGTA \\
Cyp2j6 & TTAGCCACGATCTGGGCAG & TGTCTTTGGAACTTTGTCTGCAA \\
Cyp3all & TGAAACCACCAGTAGCACACTT & CTGGGGGATAGTTCTTGGGG \\
Cyp4alo & ACCACAATGTGCATCAAGGAGGCC & CAGGTATTCCATCTCCATCACA \\
Cyp27al & GCCTTGCACAAGGAAGTGACT & AGGAATGAGTGGCTGTGTCGGGGAGAG \\
Dtd & AAGAGCAGCATGACCTCTCAC & CGCAGGGTCTCCTTAATCACA \\
Fatp2 & ACAACATTCGTGCCAAGTCTCT & CTGCCTCAAGTCAGTGCCT \\
G6ptl & GGCTACGGCTACTATCGCAC & CTCCTCCACAGCTTCTTGTAGATC \\
Gstm3 & CCCCAACTTTGACCGAAGC & AGGAGGGCATGACAAAGGAGA \\
Mct4 & GAGGTGGTTCATACCCCGGAAA & GGTGTCCATAACTTGGTTCTCCA \\
Mgstl & TCGCACTGACGAGAAGGTG & ATATGAGCGTTGCCCAGTCTCT \\
Nadcl & TCACAGCCTTCCTCTCCATGT & TGCATGAGGGCTGTAGAGAGA \\
Slc25a28 & AGCATTGCGTGATGTACCCG & ACTATTGCCTTCCTCCACATCCT \\
Slc25a36 & GTGAACCGAGTAGTGTCCCCT & CCTGTTGCTGTGACGTTCA \\
Sult ldl & ATGTCTTCAGGAGGGAGTTAGTG & CCTTGCAGTTTGAATAAGCAGC \\
Zip4 & ATGCTCCCAAAGTCGGTCAC & CATCAGGCCGGGCTTCAAA \\
Znt2 & AACTGCCAGGCGTGCCAGGG & CAGCGTATTTAACAGGCCGTC
\end{tabular}


lands) according to the manufacturer's instructions. Blood glucose levels were determined by the Accu-Chek Compact Glucose (Roche Diagnostics, Almere, The Netherlands) with 1 drop of blood obtained by orbital puncture.

\section{Authors' contributions}

MM conceived the study and supervised its design and coordination. The design of the study was set up by HB, $\mathrm{MB}$, and GH. JM hybridized the microarrays and was together with $\mathrm{HB}, \mathrm{MB}$ and $\mathrm{GH}$ involved in experimental work. Microarray analysis was performed by GH, PG, and HB. HB drafted the manuscript and GH and MM participated in its preparation. All authors have read and approved the final manuscript.

\section{Additional material}

\section{Additional file 1}

Expression of intestinal SLC transporters after a 24 hour fasting period. This file contains the expression data, fold changes, and p-values for all SLC transporters in fed and 24 hours fasted mice.

Click here for file

[http://www.biomedcentral.com/content/supplementary/1471-

2164-8-267-S1.pdf]

\section{Additional file 2}

Expression of intestinal detoxification enzymes after a 24 hour fasting period. This file contains the expression data, fold changes, and p-values for all detoxification enzymes in fed and 24 hours fasted mice.

Click here for file

[http://www.biomedcentral.com/content/supplementary/14712164-8-267-S2.pdf]

\section{Additional file 3}

Expression of intestinal ABC transporters after a 24 hour fasting period. This file contains the expression data, fold changes, and p-values for all $A B C$ transporters in fed and 24 hours fasted mice.

Click here for file

[http://www.biomedcentral.com/content/supplementary/14712164-8-267-S3.pdf]

\section{Acknowledgements}

The authors thank Rene Bakker and Bert Weijers for excellent assistance with animal experiments. This study was partially supported by a grant of the Graduate School VLAG.

\section{References}

I. van den Berghe $\mathrm{G}$ : The role of the liver in metabolic homeostasis: implications for inborn errors of metabolism. J Inherit Metab Dis |99|, I 4(4):407-420.

2. Kersten S, Seydoux J, Peters JM, Gonzalez FJ, Desvergne B, Wahli W: Peroxisome proliferator-activated receptor alpha mediates the adaptive response to fasting. J Clin Invest 1999, I03(I I): |489-1498.

3. Stenberg $P$, Luthman K, Artursson P: Virtual screening of intestinal drug permeability. J Control Release 2000, 65( I-2):23|-243.

4. Lee VH: Membrane transporters. Eur J Pharm Sci 2000, I I Suppl 2:S4I-50.
5. Steffansen B, Nielsen CU, Brodin B, Eriksson AH, Andersen R, Frokjaer $S$ : Intestinal solute carriers: an overview of trends and strategies for improving oral drug absorption. Eur J Pharm Sci 2004, 2I(I):3-16.

6. Tsuji A, Tamai I: Carrier-mediated intestinal transport of drugs. Pharm Res 1996, I3(7):963-977.

7. Anderle $P$, Huang $Y$, Sadee $W$ : Intestinal membrane transport of drugs and nutrients: genomics of membrane transporters using expression microarrays. Eur J Pharm Sci 2004, 2 I (I): I7-24.

8. Hediger MA, Romero MF, Peng JB, Rolfs A, Takanaga H, Bruford EA: The ABCs of solute carriers: physiological, pathological and therapeutic implications of human membrane transport proteins. Pflugers Arch 2004, 447(5):465-468.

9. Wacher VJ, Salphati L, Benet LZ: Active secretion and enterocytic drug metabolism barriers to drug absorption. Adv Drug Deliv Rev 200I, 46(I-3):89-102

10. Kaminsky LS, Zhang QY: The small intestine as a xenobioticmetabolizing organ. Drug Metab Dispos 2003, 3 I (I 2): I 520-I 525.

II. Danielson PB: The cytochrome $\mathbf{P 4 5 0}$ superfamily: biochemistry, evolution and drug metabolism in humans. Curr Drug Metab 2002, 3(6):56|-597.

12. Banoglu E: Current status of the cytosolic sulfotransferases in the metabolic activation of promutagens and procarcinogens. Curr Drug Metab 2000, I(I): I-30

13. Weinshilboum RM, Otterness DM, Aksoy IA, Wood TC, Her C, Raftogianis RB: Sulfation and sulfotransferases I: Sulfotransferase molecular biology: cDNAs and genes. FASEB J I 997, I I (I):3-I 4.

14. Tukey RH, Strassburg CP: Human UDP-Glucuronosyltransferases: Metabolism, Expression, and Disease. Annual Review of Pharmacology and Toxicology 2000, 40(I):58I-6I6.

15. Tew KD, Ronai Z: GST function in drug and stress response. Drug Resistance Updates 1999, 2(3): | 43.

16. Moscow JA, Dixon $\mathrm{KH}$ : Glutathione-related enzymes, glutathione and multidrug resistance. Cytotechnology 1993, I2(13): $155-170$.

17. Vatsis KP, Weber WW, Bell DA, Dupret JM, Evans DA, Grant DM, Hein DW, Lin HJ, Meyer UA, Relling MV, et al.: Nomenclature for $\mathbf{N}$ acetyltransferases. Pharmacogenetics 1995, 5(I): I-I7.

18. Arand M, Cronin A, Adamska M, Oesch F: Epoxide hydrolases: structure, function, mechanism, and assay. Methods Enzymol 2005, 400:569-588.

19. Borst P, Elferink RO: Mammalian ABC transporters in health and disease. Annu Rev Biochem 2002, 71:537-592.

20. Ferraris RP, Carey HV: Intestinal transport during fasting and malnutrition. AnnuRevNutr 2000, 20:195-219.

21. Miyauchi S, Gopal E, Fei YJ, Ganapathy V: Functional identification of SLC5A8, a tumor suppressor down-regulated in colon cancer, as a $\mathrm{Na}(+)$-coupled transporter for short-chain fatty acids. | Biol Chem 2004, 279( ( 4): I 3293-I 3296.

22. Markovich $D$, Murer H: The SLCI3 gene family of sodium sulphate/carboxylate cotransporters. Pflugers Arch 2004, 447(5):594-602.

23. Endo $S$, Nomura $T$, Chan BS, Lu R, Pucci ML, Bao $Y$, Schuster VL: Expression of PGT in MDCK cell monolayers: polarized apical localization and induction of active PG transport. Am J Physiol Renal Physiol 2002, 282(4):F618-622.

24. Mount DB, Romero MF: The SLC26 gene family of multifunctional anion exchangers. Pflugers Arch 2004, 447(5):71 0-72I.

25. Eide DJ: The SLC39 family of metal ion transporters. Pflugers Arch 2004, 447(5):796-800

26. Gill RK, Saksena S, Alrefai WA, Sarwar Z, Goldstein IL, Carroll RE, Ramaswamy K, Dudeja PK: Expression and membrane localization of MCT isoforms along the length of the human intestine. Am J Physiol Cell Physiol 2005, 289(4):C846-852.

27. McKie AT, Barlow DJ: The SLC40 basolateral iron transporter family (IREGI/ferroportin/MTPI). Pflugers Arch 2004, 447(5):80I-806.

28. Martel F: Recent advances on the importance of the serotonin transporter SERT in the rat intestine. Pharmacol Res 2006 , 54(2):73-76.

29. Liuzzi JP, Cousins RJ: Mammalian zinc transporters. Annu Rev Nutr 2004, 24:151-172.

30. Bartoloni L, Antonarakis SE: The human sugar-phosphate/phosphate exchanger family SLC37. Pflugers Arch 2004, 447(5):780-783.

31. Steinberg SJ, Wang SJ, Kim DG, Mihalik SJ, Watkins PA: Human verylong-chain acyl-CoA synthetase: cloning, topography, and relevance to branched-chain fatty acid metabolism. Biochem Biophys Res Commun 1999, 257(2):615-621.

32. Kamiyama S, Sasaki N, Goda E, Ui-Tei K, Saigo K, Narimatsu H, Jigami Y, Kannagi R, Irimura T, Nishihara S: Molecular Cloning and Characterization of a Novel 3'-Phosphoadenosine 5'-Phosphosul- 
fate Transporter, PAPST2. J Biol Chem 2006, 28 I(16): 10945-10953. physiological and pathological implications. Pflugers Arch 2004, 447(5):689-709.

34. Ishida N, Kawakita M: Molecular physiology and pathology of the nucleotide sugar transporter family (SLC35). Pflugers Arch 2004, 447(5):768-775.

35. Alberti S, Schuster G, Parini P, Feltkamp D, Diczfalusy U, Rudling M, Angelin B, Bjorkhem I, Pettersson S, Gustafsson JA: Hepatic cholesterol metabolism and resistance to dietary cholesterol in LXR\{beta\}-deficient mice. J Clin Invest 200I, I07(5):565-573.

36. Lund E, Andersson O, Zhang J, Babiker A, Ahlborg G, Diczfalusy U, Einarsson K, Sjovall J, Bjorkhem I: Importance of a Novel Oxidative Mechanism for Elimination of Intracellular Cholesterol in Humans. Arterioscler Thromb Vasc Biol 1996, 16(2):208-2I2.

37. Jia G, Takahashi R, Zhang Z, Tsuji Y, Sone $H$ : Aldo-keto reductase family B7 is the gene induced in response to oxidative stress in the livers of Long-Evans Cinnamon rats. Int J Oncol 2006, 29(4):829-838

38. Wang N, Silver DL, Thiele C, Tall AR: ATP-binding Cassette Transporter AI (ABCAI) Functions as a Cholesterol Efflux Regulatory Protein. J Biol Chem 200I, 276(26):23742-23747.

39. Yu L, Li-Hawkins J, Hammer RE, Berge KE, Horton JD, Cohen JC, Hobbs HH: Overexpression of ABCG5 and ABCG8 promotes biliary cholesterol secretion and reduces fractional absorption of dietary cholesterol. J Clin Invest 2002, I I 0(5):67I-680.

40. Kislinger T, Cox B, Kannan A, Chung C, Hu P, Ignatchenko A, Scott MS, Gramolini AO, Morris Q, Hallett MT, Rossant J, Hughes TR, Frey B, Emili A: Global survey of organ and organelle protein expression in mouse: combined proteomic and transcriptomic profiling. Cell 2006, I 25(I): I73-186.

4I. Cox B, Kislinger T, Wigle DA, Kannan A, Brown K, Okubo T, Hogan B, Jurisica I, Frey B, Rossant J, Emili A: Integrated proteomic and transcriptomic profiling of mouse lung development and Nmyc target genes. Mol Syst Biol 2007, 3:.

42. Lenaerts K, Sokolovic M, Bouwman FG, Lamers WH, Mariman EC Renes J: Starvation induces phase-specific changes in the proteome of mouse small intestine. J Proteome Res 2006, 5(9):2II3-2| 22

43. Chappell VL, Thompson MD, Jeschke MG, Chung DH, Thompson IC Wolf SE: Effects of incremental starvation on gut mucosa. Dig Dis Sci 2003, 48(4):765-769.

44. Samsom M, Fraser R, Smout AJ, Verhagen MA, Adachi K, Horowitz M, Dent I: Characterization of small intestinal pressure waves in ambulant subjects recorded with a novel portable manometric system. Dig Dis Sci 1999, 44(I I):2157-2164.

45. Lordal M, Wallen H, Hjemdahl P, Beck O, Hellstrom PM: Concentration-dependent stimulation of intestinal phase III of migrating motor complex by circulating serotonin in humans. Clin $\mathrm{Sc}$ (Lond) 1998, 94(6):663-670.

46. Liu MC, Sakakibara Y, Liu CC: Bacterial expression, purification, and characterization of a novel mouse sulfotransferase that catalyzes the sulfation of eicosanoids. Biochem Biophys Res Commun 1999, 254(I):65-69.

47. Makkar RS, Contreras MA, Paintlia AS, Smith BT, Haq E, Singh I: Molecular organization of peroxisomal enzymes: protein-protein interactions in the membrane and in the matrix. Arch Biochem Biophys 2006, 45 I (2): $128-140$

48. Pajor AM: Sodium-coupled transporters for Krebs cycle intermediates. Annu Rev Physiol 1999, 61:663-682.

49. Venkateswaran A, Laffitte BA, Joseph SB, Mak PA, Wilpitz DC, Edwards PA, Tontonoz P: Control of cellular cholesterol efflux by the nuclear oxysterol receptor LXRalpha. PNAS 2000, 97(22): |2097-12102

50. Repa J], Berge KE, Pomajzl C, Richardson JA, Hobbs H, Mangelsdorf D]: Regulation of ATP-binding Cassette Sterol Transporters $A B C G 5$ and $A B C G 8$ by the Liver $X$ Receptors alpha and beta. J Biol Chem 2002, 277(2I): 18793-18800.

5I. Fu X, Menke JG, Chen Y, Zhou G, MacNaul KL, Wright SD, Sparrow CP, Lund EG: 27-Hydroxycholesterol Is an Endogenous Ligand for Liver X Receptor in Cholesterol-loaded Cells. J Biol Chem 200I, 276(42):38378-38387.

52. Bauer M, Hamm AC, Bonaus M, Jacob A, Jaekel J, Schorle H, Pankratz $M J$, Katzenberger JD: Starvation response in mouse liver shows strong correlation with life-span-prolonging processes. Physio Genomics 2004 17(2):230-244.

53. Guengerich FP: Cytochrome P-450 3A4: regulation and role in drug metabolism. Annu Rev Pharmacol Toxicol 1999, 39:1-17.

54. Townsend DM, Tew KD, Tapiero $\mathrm{H}$ : The importance of glutathione in human disease. Biomed Pharmacother 2003, 57(34): $145-155$.
55. Battiston L, Moretti M, Tulissi P, Micheli L, Marchi P, Mazzoran L, Lunazzi G, Pozzato G: Hepatic glutathione determination after ethanol administration in rat: evidence of the first-pass metabolism of ethanol. Life Sci 1995, 56(4):24|-248.

56. Szkudelski T, Okulicz M, Bialik I, Szkudelska K: The influence of fasting on liver sulfhydryl groups, glutathione peroxidase and glutathione-S-transferase activities in the rat. J Physiol Biochem 2004 , 60(1): $1-6$

57. Di Simplicio P, Rossi R, Falcinelli S, Ceserani R, Formento ML: Antioxidant status in various tissues of the mouse after fasting and swimming stress. Eur J Appl Physiol Occup Physiol 1997, 76(4):302-307.

58. Bartlett K, Eaton S: Mitochondrial \{beta\}-oxidation. Eur J Biochem 2004, 27 I (3):462-469.

59. Beutler E, Gelbart T, Pegelow C: Erythrocyte glutathione synthetase deficiency leads not only to glutathione but also to glutathione-S-transferase deficiency. J Clin Invest |986, 77(I):38-4I.

60. Kensler TW, Wakabayashi N, Biswal S: Cell Survival Responses to Environmental Stresses Via the Keap I-Nrf2-ARE Pathway. Annual Review of Pharmacology and Toxicology 2007, 47(1):89-1 16.

61. Patsouris D, Reddy JK, Muller M, Kersten S: Peroxisome proliferator-activated receptor alpha mediates the effects of high-fat diet on hepatic gene expression. Endocrinology 2006, I47(3): $1508-15 \mid 6$.

62. Kok T, Wolters $\mathrm{H}$, Bloks VW, Havinga $\mathrm{R}$, Jansen $\mathrm{PL}$ Staels $\mathrm{B}$, Kuipers $\mathrm{F}$ : Induction of hepatic ABC transporter expression is part of the PPARalpha-mediated fasting response in the mouse. Gastroenterology 2003, I 24(I): 160-I7I.

63. Vamecq J, Latruffe N: Medical significance of peroxisome proliferator-activated receptors. Lancet | 999, 354(9173): |4|-|48.

64. Knight BL, Patel DD, Humphreys SM, Wiggins D, Gibbons GF: Inhibition of cholesterol absorption associated with a PPAR alphadependent increase in $A B C$ binding cassette transporter $A l$ in mice. J Lipid Res 2003, 44(I I):2049-2058.

65. Santamarina-Fojo S, Peterson K, Knapper C, Qiu Y, Freeman L, Cheng JF, Osorio J, Remaley A, Yang XP, Haudenschild C, Prades C, Chimini G, Blackmon E, Francois T, Duverger N, Rubin EM, Rosier M, Denefle $P$, Fredrickson DS, Brewer HB Jr.: Complete genomic sequence of the human ABCAI gene: analysis of the human and mouse ATP-binding cassette A promoter. Proc Natl Acad Sci U S A 2000 97(14):7987-7992.

66. Lee SS, Pineau T, Drago J, Lee EJ, Owens JW, Kroetz DL, FernandezSalguero PM, Westphal H, Gonzalez F): Targeted disruption of the alpha isoform of the peroxisome proliferator-activated receptor gene in mice results in abolishment of the pleiotropic effects of peroxisome proliferators. Mol Cell Biol 1995, 15(6):3012-3022.

67. Gentleman RC, Carey VJ, Bates DM, Bolstad B, Dettling M, Dudoit S, Ellis B, Gautier L, Ge Y, Gentry J. Hornik K, Hothorn T, Huber W, lacus S, Irizarry R, Leisch F, Li C, Maechler M, Rossini AJ, Sawitzki G, Smith C, Smyth G, Tierney L, Yang JY, Zhang J: Bioconductor: open software development for computational biology and bioinformatics. Genome Biol 2004, 5(I0):R80.

68. Wu Z, Irizarry RA, Gentleman R, Martinez-Murillo F, Spencer F: A Model-Based Background Adjustment for Oligonucleotide Expression Arrays. Journal of the American Statistical Association 2004 99(468):909-917.

69. Smyth GK: Limma: linear models for microarray data. In Bioinformatics and Computational Biology Solutions using $R$ and Bioconductor Volume I. Edited by: R. Gentleman VCSDRIWH. New York, Springer; 2005:397-420.

70. Kendziorski CM, Newton MA, Lan H, Gould MN: On parametric empirical Bayes methods for comparing multiple groups using replicated gene expression profiles. Stat Med 2003, 22(24):3899-39|4.

71. Kooperberg C, Aragaki A, Strand AD, Olson JM: Significance testing for small microarray experiments. Stat Med 2005, 24(I 5):228I-2298.

72. Gottardo R, Pannucci JA, Kuske CR, Brettin T: Statistical analysis of microarray data: a Bayesian approach. Biostatistics 2003, 4(4):597-620

73. Smyth GK: Linear models and empirical bayes methods for assessing differential expression in microarray experiments. Stat Appl Genet Mol Biol 2004, 3:Article3.

74. Kussmann M, Raymond F, Affolter M: OMICS-driven biomarker discovery in nutrition and health. J Biotechnol 2006, I 24(4):758-787.

75. Afman L, Muller M: Nutrigenomics: from molecular nutrition to prevention of disease. J Am Diet Assoc 2006, 106(4):569-576.

76. Muller M, Kersten S: Nutrigenomics: goals and strategies. Nat Rev Genet 2003, 4(4):3। 5-322 